\section{Linkage analysis in an autosomal dominant 'zonular nuclear pulverulent' congenital cataract, mapped to chromosome 13q11-13}

PATRICK WATTS, MARK REES, ANGUS CLARKE, LYN BECK, CAROL LANE, MICHAEL J. OWEN, JONATHON GRAY
P. Watts
L. Beck
C. Lane

Department of

Ophthalmology

University Hospital of Wales

Cardiff CF4 4XN, UK

M. Rees

M.J. Owen

Department of

Psychological Medicine

University of Wales College

of Medicine

Cardiff CF4 4XW, UK

\section{A. Clarke}

J. Gray

Institute of Medical Genetics University Hospital of Wales Cardiff CF4 4XN, UK

Mr P. Watts, MS, FRCS, FRCOphth

58 Crystal Wood Road Cardiff CF14 4HW, UK

e-mail: patrick.watts@net.ntl.com

This work was supported by a grant from the MRC.

J.G. receives support from Tenovus and Macmillian charities

Received: 17 May 1999 Accepted in revised form: 13 September 1999

\section{Abstract}

Purpose To determine by linkage analysis the chromosomal locus responsible for autosomal dominant congenital cataract (ADCC) in a four-generation Welsh pedigree.

Methods The family pedigree was traced through two members of the family attending the hospital for treatment of their cataracts. Twenty-five members of the family were examined ophthalmologically and blood was collected with consent for genetic linkage analysis.

Results Fifteen members of this family were known to have bilateral congenital cataracts, of whom 11 had a cataract extraction prior to examination. The youngest member of the pedigree was 5 years old and the oldest was 78 years old. Four children, unoperated at the time of this study, had a phenotypically identical morphology of their zonular pulverulent congenital cataracts. The known loci for congenital cataract were excluded. Significant lod scores for markers in the 13q11-13 region were detected with a $Z_{\max }$ of 3.59 D13S1236 $(\theta=0.00)$.

Conclusions We report linkage of an ADCC of the zonular pulverulent type to chromosome 13q11-13 in a four-generation family.

Key words Autosomal, Cataract, Dominant, Linkage, Pulverulent, Zonular

Congenital cataracts are a significant cause of visual handicap. The prevalence of congenital cataract varies between 1 and 6/10000 1,2 live births and approximately $25 \%$ of these have a genetic basis. ${ }^{3}$ Although all three types of inheritance have been described, autosomal dominant transmission is the most frequently reported. ${ }^{4}$ The morphological description of the various forms of inherited cataracts is based on the location of the opacities in the lens.

Accordingly they may be classified as:

(a) zonular, where the opacity occupies a

discrete zone of the lens (i) nuclear, (ii) lamellar, (iii) sutural, (iv) capsular; and (b) polar where the opacities occupy either the anterior or posterior pole of the lens in the subcapsular cortex. ${ }^{5}$ Eponymous labels have been used to classify various inherited cataracts. These either represent the family name of the pedigree in which they were first described (as in the Coppock cataract ${ }^{6}$ ), the author who described the morphology of the cataract (for example the Marner cataract ${ }^{7}$ ) or the description of the morphology of the cataract itself (as in the cerulean cataract ${ }^{8}$ ).

There are now about 10 loci for autosomal dominant cataract that have been mapped, reviewed recently by Hejtmancik ${ }^{9}$ (Table 1 ). Linkage to chromosome $2 \mathrm{q}$ is associated with a Coppock-like cataract, which was originally described as a 'disc like opacity deep in the lens' with occasional triradiate pattern of greater density. ${ }^{10}$ The Marner cataract, described as finely dispersed opacities in the embryonic nucleus with condensations at 10, 2 and 6 o'clock, with additional peripheral zonal dots and peripheral 'riders', has been linked to chromosome 16q22. ${ }^{7}$ A mutation on the CRYBB2 gene in chromosome 22q has been associated with a cerulean cataract, which is a blue and white dot cataract scattered concentrically throughout the lens with occasional central opacities arranged radially. ${ }^{11}$ Armitage et al. ${ }^{12}$ have also described a similar phenotype linked to chromosome 17q24. A zonular sutural opacity which consisted either of a dense opacity affecting both the anterior and posterior lens sutures, or of a series of dots forming a hazy cloud along the sutures, has been linked to chromosome 17q11-12, with beta $\mathrm{A}_{3} / \mathrm{A}_{1}$ crystallin a possible candidate gene. ${ }^{13}$

Mutations have been identified in genes for lens crystallins and for gap junctional proteins (connexins). Lens crystallin gene mutations have been identified on $22 q^{11} 17 q^{13}$ and $2 q^{10}$ Mutations in a gap junction protein gene, connexin 50, were identified on $1 q^{14}$ and most recently in the connexin 46 gene $^{15}$ on 
Table 1. Autosomal dominant cataract genetic linkage

\begin{tabular}{lll}
\hline Morphological description of cataract & Chromosomal linkage & Authors \\
\hline Progressive central zonular opacity including the lens sutures & $1 \mathrm{p} 36$ & Eiberg et al. $(1988)^{21}$ \\
Zonular pulverulent (Coppock) & $1 \mathrm{q}$ & Renwick and Lawler $(1963)^{25}$ \\
Posterior polar & $1 \mathrm{p}$ & Ionides et al. $(1997)^{26}$ \\
Polymorphic & $2 \mathrm{q} 33-35$ & Rogaev et al. $(1996)^{27}$ \\
Zonular pulverulent & $13 \mathrm{q} 11$ & Mackay et al. $(1997)^{22}$ \\
Posterior polar progressive zonular & $16 \mathrm{q} 22$ & Eiberg et al. $(1998)^{28}$ \\
Anterior polar & $17 \mathrm{p}$ & Berry et al. $(1996)^{29}$ \\
Blue dot (cerulean) & $17 \mathrm{q} 24$ & Armitage et al. $(1995)^{12}$ \\
Zonular and sutural & $17 \mathrm{q} 11-12$ & Padma et al. $(1995)^{13}$ \\
Peripheral blue and white dots (cerulean) & 22 & Kramer et al. $(1996)^{8}$
\end{tabular}

chromosome $13 q$, responsible for a zonular pulverulent cataract in two families of British lineage.

Linkage analysis was performed to determine the possible locus of a central zonular pulverulent (powdery) cataract with anterior and posterior cortical snowflakelike opacities in a four-generation Welsh family showing autosomal dominant transmission.

\section{Patients and methods}

Twenty-five members of a Welsh family were contacted through the two index cases followed up in our hospital for their cataracts. A detailed clinical and ophthalmological history was obtained on all patients. Clinical examination included an assessment of the visual acuity, slit-lamp assessment of the lens after pupillary dilation and fundus examination. Where the cataract was still present a slit-lamp photograph of the lens was attempted. A general physical examination of the affected family members was also carried out to rule out any associated systemic abnormalities.

Twenty millilitres of blood was collected in EDTA tubes for DNA isolation. After the DNA was extracted, using a conventional phenol/chloroform method, genotyping was performed using 46 fluorescently labelled polymorphic microsatellite markers. Using a three-step polymerase chain reaction protocol the markers were separated on polyacrylamide gels and analysed using the Genescan and Genotype software (Rees MI et al., Hum Genet, in press). Haplotype analysis was performed using the MegaBASE database program. In the linkage analysis lod scores were calculated using the MLINK program, FASTLINK. ${ }^{16}$ Multipoint analysis on regions with a positive two point lod score, utilised the LINKMAP program. ${ }^{17}$

Informed consent was obtained in all patients and ethics approval for the study was granted by the local ethics committee at the University Hospital of Wales.

\section{Results}

A four-generation Welsh family of 25 members with a fully penetrant congenital zonular pulverulent cataract were examined. Pedigree analysis is consistent with autosomal dominant inheritance of bilateral congenital cataracts (Fig. 1). Fifteen members of the family had bilateral cataracts of whom 11 had had cataract surgery and were aphakic or pseudophakic at the time of the study. The age range in this family was 5-78 years. The mean age at diagnosis was $5.6 \pm 4.6$ years (range: from birth to 10 years). The mean age at the time of cataract surgery was 12.4 years \pm 4.6 years (range: 5-20 years). All the affected members of the pedigree who were operated on had a best-corrected visual acuity of $6 / 12$ or better.

A similar morphological form of cataract was seen in all the four children who were examined. The cataract was bilateral and consisted of a central pulverulent (dustlike) opacity affecting the embryonal, fetal and infantile nucleus of the lens. This was surrounded by a varying density of snowflake-like opacities in the anterior and posterior cortical region of the lens with a posterior subcapsular element (Fig. 2). The ocular examination in all affected members of the family was otherwise normal with normal corneal diameters. There were no associated systemic abnormalities detected.

Linkage analysis identified four markers with positive lod scores in the $13 q 11-13$ region with a $Z_{\max }$ of 3.59 at D13S1236 $(\theta=0.00)$. A multipoint analysis yielded a $Z_{\max }$ of $5.11(\theta=0.00)$ (Rees MI et al., Hum Genet, in press).

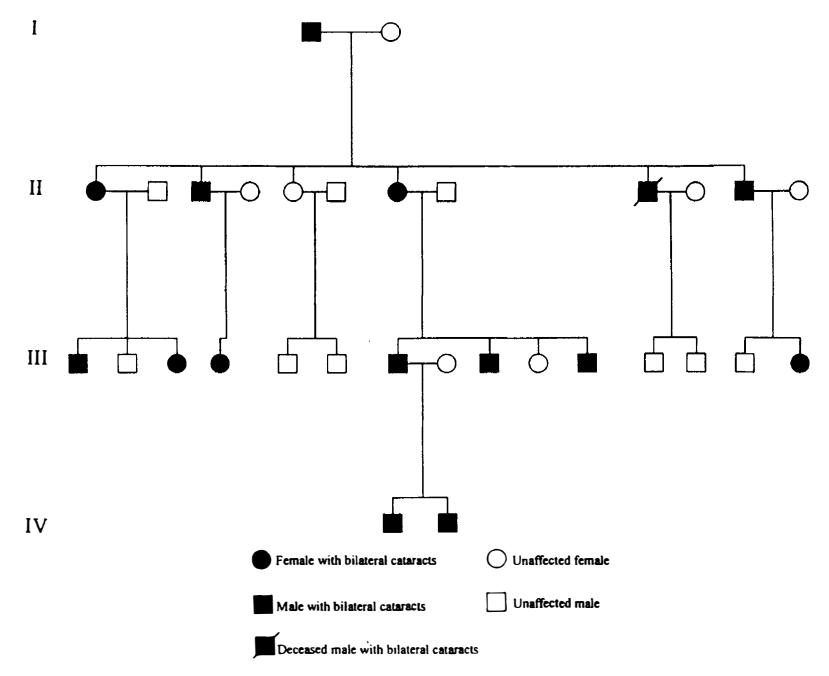

Fig. 1. Pedigree of a family with autosomal dominant zonular pulverulent cataracts. 


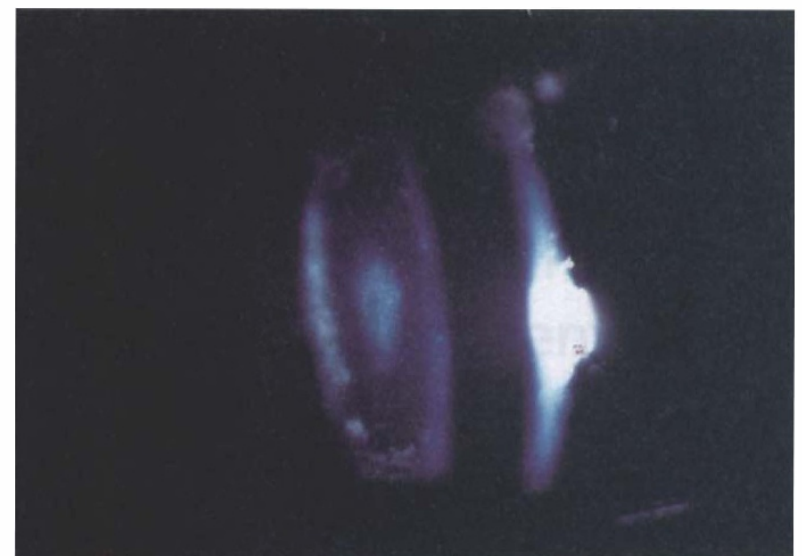

FIg. 2. A slit-lamp photograph of a patient's cataract. It consisted of a central pulverulent (dust-like) opacity, surrounded by a varying density of snowflake-like opacities in the anterior and posterior cortical region of the lens with a posterior subcapsular element.

\section{Discussion}

Genetic linkage for a number autosomal dominant cataracts has previously been reported (Table 1). It is seen that clinically identical morphological forms of cataract may be assigned to different loci. ${ }^{18,19}$

Zonular pulverulent cataracts, phenotypically described a number of fine dots occupying the embryonic and fetal nucleus, have been associated with a mutation in the human connexin 50 gene on chromosome 1q. ${ }^{14}$ More recently Mackay et al. ${ }^{15}$ have described mutations in connexin 46 on chromosome $13 \mathrm{q}$ associated with zonular pulverulent cataract, described as coarse granular opacities towards the central fetal nucleus and fine dust-like opacities in the juvenile cortex.

Clinical presentation of the patients with cataract demonstrates that this was not visually disabling in the first years of life, as evidenced by the good visual acuities in those operated on. Visual disability was caused by the progression of the cataract towards the end of the first and in the second decade of life. Though an intrafamilial heterogeneity in the phenotypic expression of ADCC has been reported, ${ }^{20}$ the zonular pulverulent cataract with peripheral white snowflake-like opacities and a posterior subcapsular element was symmetrical and bilateral in the 4 patients in this pedigree who were unoperated at the time of examination.

The cataract in this pedigree bears some resemblance to those described in other studies. These have been linked to chromosome $1 q,{ }^{14} 1 p 36^{21}$ and $17 q 11-12 .{ }^{13}$ The locus in this study was identified after a report of a cataract of a similar description, but with variability as to the zonular location, linked to a new locus $13 q^{22}$ and a mutation in a gene for a gap junction protein known as connexin 46 (GJA3) in two families of British descent. ${ }^{15}$

Connexins are structural proteins of intercellular channels that comprise the gap junctions; they are essential in allowing intercellular communication. This communication is especially important in the vascular lens, where the channels allow the lens cells to form a functional syncytium which in turn will allow ions, second messengers and metabolites to be shared. ${ }^{23}$ Apart from the lens epithelium, the lens fibre cells do not have cellular organelles and cannot support oxidative phosphorylation or an active metabolism. It has hence been hypothesised that the gap junctions allow the maintenance of intercellular ionic conditions necessary to prevent the precipitation of the lens crystallins and the formation of a cataract. ${ }^{24}$

To our knowledge our study is only the second report of linkage of zonular pulverulent cataract to chromosome 13q11-13 in an unrelated family. The cataract locus in this family is now being further characterised and the analysis of candidate genes in this region is under way; it is possible that a similar mutation in the gap junctional protein gene as reported by Mackay et al. ${ }^{15}$ will be identified.

\section{References}

1. James LM, McClearon AB, Waters GD. Congenital malformation surveillance data for birth defects prevention: Metropolitan Atlanta congenital defects program (MACDP) 1968-1991 and birth defects monitoring program (BDMP) 1970-1991. Tetralogy 1993;48:545-709.

2. Stewart-Brown SL, Haslum MN. Partial sight and blindness in children of the 1970 birth cohort at 10 years of age. J Epidemiol Community Health 1988;42:17-23.

3. Francois J. Genetics of cataract. Ophthalmologica (Basel) 1982;184:61-71.

4. Merin S. Inherited cataracts. In: Merin S, editor. Inherited eye disease: diagnosis and clinical management. New York: Marcel Dekker, 1991:86-120.

5. Lambert SR, Drack AV. Infantile cataracts. Surv Ophthalmol 1996;40:427-58.

6. Nettleship E, Ogilvie FM. A peculiar form of hereditary congenital cataract. Trans Ophthalmol Soc UK 1906;26:191-207.

7. Marner E, Rosenberg T, Eiberg H. Autosomal dominant congenital cataract: morphology and genetic mapping. Acta Ophthalmol (Copenh) 1989;67:151-8.

8. Kramer P, Yount J, Mitchell T, LaMorticella D, Carrero-Valenzuela R, Lovrein E, Maumenee I, Litt M. A second gene for cerulean cataracts maps to the $\beta$-crystallin region on chromosome 22. Genomics 1996;35:539-42.

9. Hejtmancik JF. The genetics of cataract: our vision becomes clearer. Am J Hum Genet 1998;62:520-5.

10. Brakenhoff RH, Henskens HAM, van Rossum MWPC, Lubsen NH, Schonmakers JGG. Activation of $\gamma$-E-crystallin pseudogene in the human hereditary Coppock-like cataract. Hum Mol Genet 1994;3:279-83.

11. Litt M, Carrero-Valenzuela R, LaMorticella DM, Schultz DW, Mitchell TN, Kraemer P, et al. Autosomal dominant cerulean cataract is associated with a chain termination mutation in the human $\beta$-crystallin gene CRYBB2. Hum Mol Genet 1997;6:665-8.

12. Armitage MM, Kivilin JD, Ferell RE. A progressively early onset cataract gene maps to human chromosome 17q24. Nature Genet 1995;9:37-40.

13. Padma T, Ayyagari R, Murty JS, Basti S, Fletcher T, Rao GN, et al. Autosomal dominant zonular cataract with sutural opacities localised to chromosome 17q11-12. Am J Hum Genet 1995;57:840-5.

14. Shiels A, Mackay D, Ionides A, Berry V, Moore A, Bhattacharya S. A missense mutation in the human connexin 50 gene (GJA8) underlies autosomal dominant 'zonular pulverulent' cataract on chromosome 1q. Am J Hum Genet 1998;62;526-32. 
15. Mackay D, Ionides A, Kibar Z, Rouleau G, Berry V, Moore A, et al. Connexin 46 mutations in autosomal dominant congenital cataract. Am J Hum Genet 1999;64:1357-64.

16. Cottingham RW, Idury RM, Schaffer AA. Faster sequential genetic linkage computations. Am J Hum Genet 1993;53:252-63.

17. O'Connell JR, Weeks DE. The VITESSE algorithm for rapid exact multilocus linkage analysis via genotype set-recoding and fuzzy inheritance. Nature Genet 1995;11:402-8.

18. Conneally PM, Wilson AF, Merritt AD, Helveston EM, Palmer CG, Wang LY. Confirmation of genetic heterogeneity in autosomal dominant forms of congenital cataracts from linkage studies. Cytogenet Cell Genet 1978;22:295-7.

19. Lund AM, Eiberg H, Rosenberg T, Warburg M. Autosomal dominant cataract: linkage relations; clinical and genetic heterogeneity. Clin Genet 1992;41:65-9.

20. Scott MH, Hejtmancik JF, Wozencraft LA, Reuter LM, Parks MM, Kaiser-Kupfer MI. Autosomal dominant congenital cataract: interocular phenotypic variability. Ophthalmology 1994;101:866-71.

21. Eiberg H, Lund AM, Warburg M, Rosenberg T. Assignment of congenital cataract Volkmann type (CCV) to chromosome 1p36. Hum Genet 1995;96:33-8.
22. Mackay D, Ionides A, Berry V, Moore A, Bhattacharya S, Shiels A. A new locus for dominant 'zonular pulverulent' cataract, on chromosome 13. Am J Hum Genet 1997;60:1474-8.

23. White TW, Goodenough DA, Paul DL. Targeted ablation of connexin 50 in mice results in microphthalmia and zonular pulverulent cataracts. J Cell Biol 1998;143:815-25.

24. Mathias RT, Rae JL, Baldo GJ. Physiological properties of the normal lens. Physiol Rev 1997;77:21-50.

25. Renwick JH, Lawler SD. Probable linkage of a congenital cataract locus and the Duffy blood group locus. Ann Hum Genet 1963;27:67-84.

26. Ionides ACW, Berry V, Mackay DS, Moore AT, Bhattacharya SS, Shiels A. A locus for autosomal dominant posterior polar cataract on chromosome 1p. Hum Mol Genet 1997;6:47-51.

27. Rogaev EI, Rogaev EA, Korovaitseva GI, Farrer LA, Petrin AN, Keryanov SA, et al. Linkage of polymorphic congenital cataract to the $\gamma$-crystallin gene locus on human chromosome 2q33-35. Hum Mol Genet 1996;5:699-703.

28. Eiberg H, Marner E, Rosenberg T, Mohr J. Marner's cataract (CAM) assigned to chromosome 16: linkage to haptoglobin. Clin Genet 1988;34:272-5.

29. Berry V, Ionides ACW, Moore AT, Plant C, Bhattacharya SS, Shiels A. A locus for autosomal dominant anterior polar cataract on chromosome 17p. Hum Mol Genet 1996;5:415-9. 